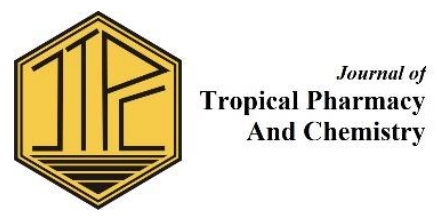

\title{
ANTIOXIDANT ASSAY OF THE ETHANOLIC EXTRACT OF THREE SPECIES OF RATTAN FRUITS USING DPPH METHOD
}

\author{
Heriad Daud Salusu 1,2,*, Farida Aryani², Abdul Rasyid Zarta', Edy Budiarso ${ }^{3}$, \\ Irawan Wijaya Kusuma ${ }^{4}$, Enos Tangke Arung ${ }^{4}$ \\ ${ }^{1}$ Graduate School of Forest Science, Faculty of Forestry, Mulawarman University, \\ Samarinda 75119, Indonesia. \\ ${ }^{2}$ Laboratory of Wood Properties and Product Analysis, State Agriculture Polytechnic of \\ Samarinda, Samarinda 75131, Indonesia \\ ${ }^{3}$ Laboratory of Wood Preservative, Faculty of Forestry, Mulawarman University. \\ Samarinda 75119, Indonesia \\ ${ }^{4}$ Laboratory of Forest Product Chemistry Faculty of Forestry, Mulawarman University. \\ Samarinda 75119, Indonesia \\ *Corresponding author: risaldaud@gmail.com
}

\begin{abstract}
The bioactivity of some species of rattan fruit has been previously studied and it was found that it has potential antioxidant agents. This study was conducted to determine the antioxidant content in three species of edible rattan fruit, namely Calamus manan Miq., Calamus ornatus B1. and Calamus caesius Bl by using the DPPH method, whereby the test was carried out on the pericarp, flesh, and seeds of each fruit. The research findings revealed that phytochemical compounds, i.e. flavonoids, tannins, and triterpenoids are found almost in all parts of the fruit, while steroid is not found in any of the three species of the fruit. The antioxidant activity found in the fruit of $C$. caesius $\mathrm{Bl}$ is strong, meanwhile the antioxidant activity in the fruit of $C$. manan Miq only strong in its pericarp and seeds, but it is moderate in its flesh. The antioxidant activity found in the fruit of $C$. ornatus $\mathrm{Bl}$. is strong in its pericarp and seeds, but it is moderate in its flesh. Therefore, these three species of rattan fruit are potential as antioxidant agents.
\end{abstract}

Keywords: antioxidant, calamus, flesh, pericarp, seed

Submitted on: 19 May 2018

Accepted on: 26 September 2018

DOI: https://doi.org/10.25026/jtpc.v4i4.170

\section{INTRODUCTION}

Rattan is a typical tropical plant whose stem is utilized as raw materials to produce a variety of crafts and furniture. Besides its stem, rattan also produces edible fruit that in several places this fruit can also be useful for health. Ripa [1] stated that the fruit of Calamus rotang $\mathrm{L}$ was potential for an anti-diarrheal agent. According to [2], rattan fruit can serve as a 
medicine to relieve cough, diabetes, and abdominal disorders. Furthermore, he stated that rattan fruit contains Vitamin A and $\mathrm{C}$, and minerals such as $\mathrm{Ca}, \mathrm{Fe}, \mathrm{Mg}, \mathrm{Zn}$ and K. Uddin [3] stated that the fruit of Calamus tenuis Roxb is used to treat diarrhea.

The three species of fruit analyzed in this study are the species of rattan which commonly grow in the forest area of East Kalimantan. They are $C$. manan Miq., $C$. caesius Bl. and $C$. ornatus Bl., all of which bear edible fruit. Until recently, the fruit of the three species of rattan has not been utilized maximally, except for its stems which have been known as having a high commercial value. The information about the benefits of rattan fruit is not sufficiently available. The knowledge and experiences about its benefits are limited only to the local people living around the forests. They make use of this fruit to relieve pains in a toothache and to treat a diarrhea. This information can be used as a preliminary guide to developing rattan fruit especially with regard to benefits for human health. Some species of rattan fruit that have been studied include $C$. erectus Roxb which contains bio-activity which is potential as antioxidant and antidiabetic agents because of its high content of phenol [4]. Moreover, Ahmed [5] in his study on $C$. tenuis Roxb. found that the phytochemical content in the rattan fruit is related to its bio-activity potentials, that is, antioxidant and cytotoxic.

Based on the background above, this study intended to screen the phytochemical compounds and to determine antioxidant capacity of the three species of rattan fruit, namely $C$. manan Miq, $C$. caesius $\mathrm{Bl}$., and $C$. ornatus $\mathrm{Bl}$ by using DPPH method. The parts of the fruit assayed were its pericarp, flesh and seeds. The results of the study will show the part of the fruit that has a better antioxidant content and also will know the type of rattan which has better antioxidant properties.

\section{MATERIALS AND METHOD}

\section{Plant Materials}

The fruits of the three species of rattan, i.e. C. manan Miq., C. caesius Bl., and $C$. ornatus $\mathrm{Bl}$. each separated from the pericarp, flesh and seeds, then each part of the fruit that has been separated dried at room temperature before they were processed to produce rattan fruit powder. Then, the fruit powder was extracted by using maceration method with ethanol as a solvent. The powder sample was soaked in the ethanol for 48 hours with the ratio of 1 : 10 (powder: solvent). The result of maceration was evaporated using rotary evaporator at the temperature of $30-40{ }^{\circ} \mathrm{C}$ so that rough extract was obtained.

\section{Reagents}

Ethanol, ethyl acetate, DPPH (1,1diphenyl-2-picrylhydrazyl), DMSO (dimethyl sulfoxide), distilled water, chloroform, sulfuric acid, hydrochloric acid, acetate lead solution, potassium iodide, acetic acid, sodium hydroxide, alcohol, and ascorbic acid.

\section{Phytochemicals screening}

\section{Alkaloids assay [6]}

An amount of $1 \mathrm{ml}$ of dragendorff's solution was added into $5 \mathrm{ml}$ of extract and added with $2 \mathrm{ml}$ of $\mathrm{HCl}$. If the color of the solution turned into orange or red color, it indicated that the extract contained alkaloids.

\section{Flavonoids assay [6]}

An amount of $1 \mathrm{ml}$ of extract was mixed with some drops of dilute sodium hydroxide $(\mathrm{NaOH} 1 \%)$. An intense yellow colour was appeared in the test tube. It became colourless when on addition of a 
few drop of dilute acid that indicated the presence of flavonoids.

\section{Saponin assay [7]}

Saponin was assayed by pouring 10 $\mathrm{ml}$ of hot water in the reaction tube containing $1 \mathrm{ml}$ of the tested sample which had been dissolved into acetone. Then, the solution was cooled and shaken for 10 seconds. The formation of a steady foam which occurred for 10 minutes with the height of 1-10 cm and would not disappear when it was given 1 drop of $\mathrm{HCl} 2 \mathrm{~N}$, indicated the extract contained saponins.

\section{Tanin Assay [6]}

Tannin was assayed by putting 10 $\mathrm{ml}$ extract solution into a reaction tube and adding acetate lead solution $\left(\mathrm{CH}_{3} \mathrm{COO}\right)_{2} \mathrm{~Pb}$ $1 \%$. Tannins were positive if there was yellow sediment found in the reaction.

\section{Triterpenoid and Steroid Assay [7]}

Triterpenoids and Steroids were identified by using the mixture of acetic acid anhydride and concentrated sulfuric acid. This is commonly known as Liebermann-Burchard reaction. Ten drops of acetic acid anhydride and 2 drops of concentrated sulfuric acid were added in series into $1 \mathrm{ml}$ of the tested sample which had been dissolved in acetone. The tested sample was shaken and left for several minutes. Red and purple colors found in the reaction showed the presence of triterpenoids, while green and blue colors indicated the presence of steroids.

\section{Antioxidants Analysis}

Antioxidants were analyzed by using a method suggested by [8] with a modification. The absorbance of the extracted sample toward free radicals was assayed by using Spectrophotometer at a room temperature $\left(25{ }^{\circ} \mathrm{C}\right)$ with the wave length of $517 \mathrm{~nm}$ and using DPPH (1.1diphenyl2-picrylhydrazyl) solution, which served as free radicals and ascorbic acid was used as a positive control.

Referring to the values of absorbance in the extracted sample, the antioxidant activities were determined based on the percentage of relative inhibition using the following equation:

Relative Inhibition Activity $(\%)=\frac{\mathrm{A}_{0}-\mathrm{A}_{1}}{\mathrm{~A}_{0}} \times 100 \%$

where $\mathrm{A}_{0}$ is the absorbance of $\mathrm{DPPH}$, and $A_{1}$ is the absorbance of extract sample. The antioxidant activities were determined based on the value of $\mathrm{IC}_{50}$ (inhibitory concentration), i.e. the amount of concentrated solution of sample needed to inhibit $50 \%$ of DPPH, which was calculated by using regression equation where the extract concentration served as its abscissa (axis X) and the value of the relative inhibition served as its ordinate (axis Y). The value of $\mathrm{IC}_{50}$ was calculated at $50 \%$ relative inhibition using the equation as follows: $\mathrm{Y}=\mathrm{b}+\mathrm{aX}$

\section{RESULT AND DISCUSSION}

\section{Phytochemical Contents}

Phytochemical is a compound which gives plants their distinctive smells, tastes and colors. The Phytochemical compound also gives a variety of potential benefits for human health. According to [9] some phytochemical components in fruit such as tannin, flavonoids, and triterpenoids serve as inhibitors against free radicals and function as antioxidant agents. In this research, phytochemical testing was carried out on ethanol extracts on pericarp, flesh and seeds of the three species of rattan fruit. Ethanol does not hydrolyze compounds and it is easy to evaporate because of its low boiling point and it is good for thermolabile compounds. [7] reported that the use of ethanol was good for initial extraction. Flavonoids, alkaloids, tannins, saponins, triterpenoids, and 
steroids are the phytochemical compounds which were assayed in this research. The assays were conducted to the pericarp, flesh, and seeds of the three species of rattan fruit.

Table 1. Phytochemical contained in fruit on three species of rattan

\begin{tabular}{|c|c|c|c|c|c|c|}
\hline Samples & Flavonoid & Alkaloid & Tannin & Saponin & Triterpenoid & Steroid \\
\hline \multicolumn{7}{|l|}{ C. manan } \\
\hline \multicolumn{7}{|l|}{ Miq. } \\
\hline Pericarp & + & + & + & + & + & - \\
\hline Flesh & + & - & + & + & + & - \\
\hline Seed & + & + & + & - & + & - \\
\hline \multicolumn{7}{|c|}{ C.caesius Bl. } \\
\hline Pericarp & + & + & - & - & + & - \\
\hline Flesh & + & - & + & + & + & - \\
\hline Seed & + & + & + & - & + & - \\
\hline \multicolumn{7}{|c|}{ C. ornatus B1. } \\
\hline Pericarp & + & + & + & - & + & - \\
\hline Flesh & - & - & + & - & + & - \\
\hline Seed & + & - & + & - & + & - \\
\hline
\end{tabular}

Note : presence $(+)$

absence (-)

The results of the assays on Table 1 shows that the fruit extract of $C$. manan Miq contains flavonoids, tannins, and triterpenoids which are found in its pericarp, flesh, and seeds; alkaloids are found in its pericarp and seeds; saponins are found in its pericarp and seeds, while steroids are not detected. The fruit extract of Calamus caesius Bl. contains flavonoids and triterpenoids in its pericarp, flesh, and seeds; alkaloids in its pericarp and seeds, tannins in its flesh and seeds; saponins in its flesh; but steroids are not detected. The fruit extract of Calamus ornatus Bl. contains flavonoids, tannins, and triterpenoids which are found in the three parts of the fruit; alkaloids are found in its pericarp; but saponins and steroids are not detected. Generally, flavonoids and triterpenoids are identified in the three species of fruit, while steroids are not detected. Alkaloids are commonly found in the pericarp and seeds, but they are not detected in the flesh of the fruit. Tannins were found almost in all parts of the fruit, except in the pericarp of $C$. caesius $\mathrm{Bl}$. Saponins were not evenly distributed in the three species of fruit. Especially in $C$. ornatus Bl., saponins are not found at all. The findings showed that phytochemical compounds are observed and distributed in three different species of rattan fruit, in which the parts of the fruit were assayed separately. A study conducted by [10] on the Lephisanthes amoenea fruit showed a similar result, where flavonoids are found in all parts of the fruit. In addition, the distribution of phytochemical compounds are mostly found in seeds and pericarp. Some previous studies showed that the existence of phytochemical compounds in plants are influenced by some factors such as adaption to the environmental factor and the growth of each individual species. According to [11], the distribution of alkaloid content in various species of plant 
is different, depending on the environmental factors and the specific growth of each type of plant. Toxic feature in alkaloid is very useful as the defense of plant against predators. Konarska and Domaciuk [12] stated that tannins are mostly accumulated in the pericarp and mesocarp of Viburnum opulus and Viburnum lantana. Moreover, according to [13], there are some factors which influence the composition and distribution of saponins in plants, for example, the protection level against predator attacks and the changes of the environment; the protection on the reproductive organs during the growth of fruit and the formation of tubers. The existence of phytochemical compounds in the three species of rattan fruit in this study indicates their potentials as natural antioxidant agents.

\section{Antioxidant Capacity}

The antioxidant capacity were assayed by using DPPH method with ascorbic acid as its positive control. The parameter of this method was expressed as the value of the Inhibition Concentration of $50 \%\left(\mathrm{IC}_{50}\right)$ namely the concentration value which could inhibit 50\% of free radical activities (DPPH). DPPH is free radicals which are stable in a room temperature having electrons and hydrogen, and form a stable molecule. The absorbance of free radicals occurs when the antioxidant compounds which can give hydrogen atom have been bond to DPPH which results in the changes of violet colors into yellow colors. The absorbance of DPPH was measured by using spectrophotometer at the wavelength of $517 \mathrm{~nm}$. Antioxidant activity on the pericarp, flesh, and seeds of the three species of rattan fruit and ascorbic acid as a positive control is displayed in Figure 1 to Figure 3.

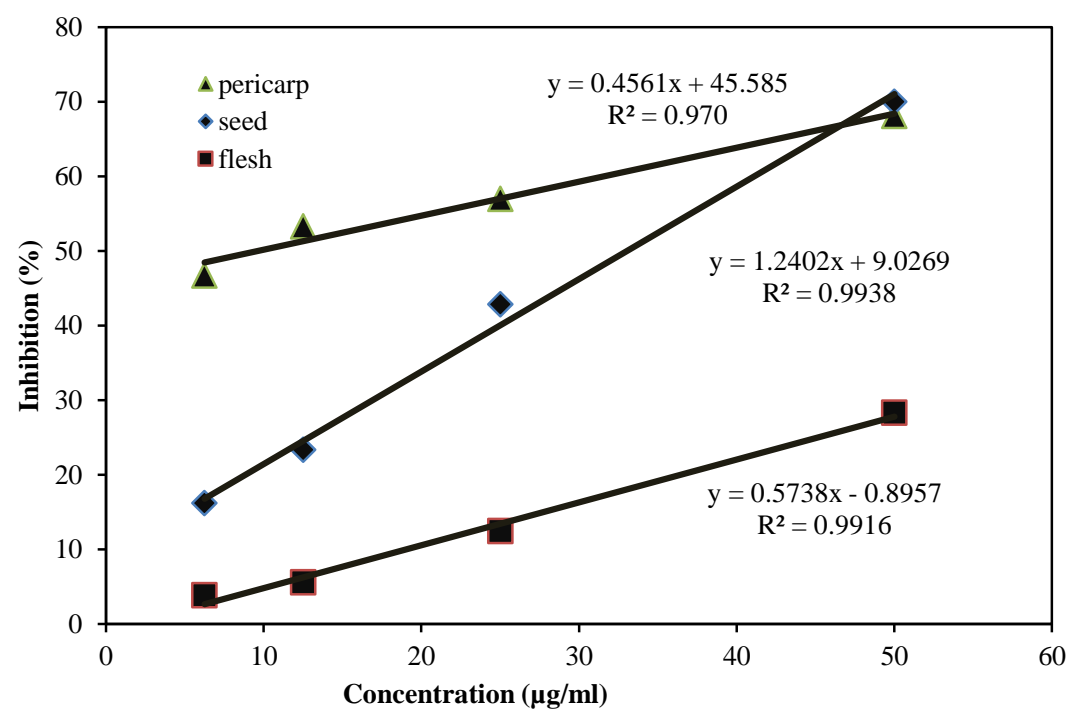

Figure 1. Antioxidant Activity in the Pericarp, Flesh and Seeds of Calamus ornatus B1., and Ascorbic Acid 


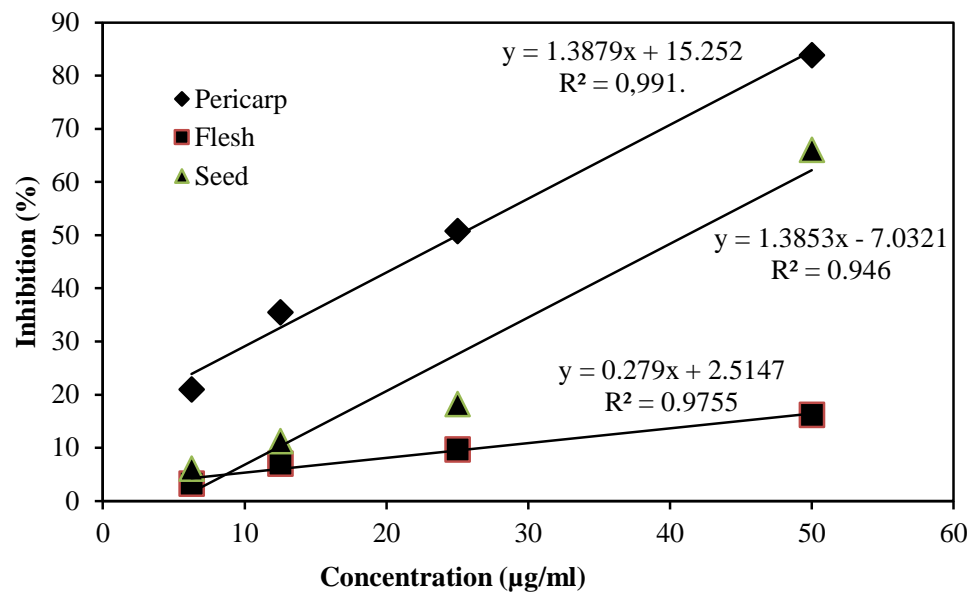

Figure 2. Antioxidant Activity in the Pericarp, Flesh and Seeds of Calamus manan Miq., and Ascorbic Acid

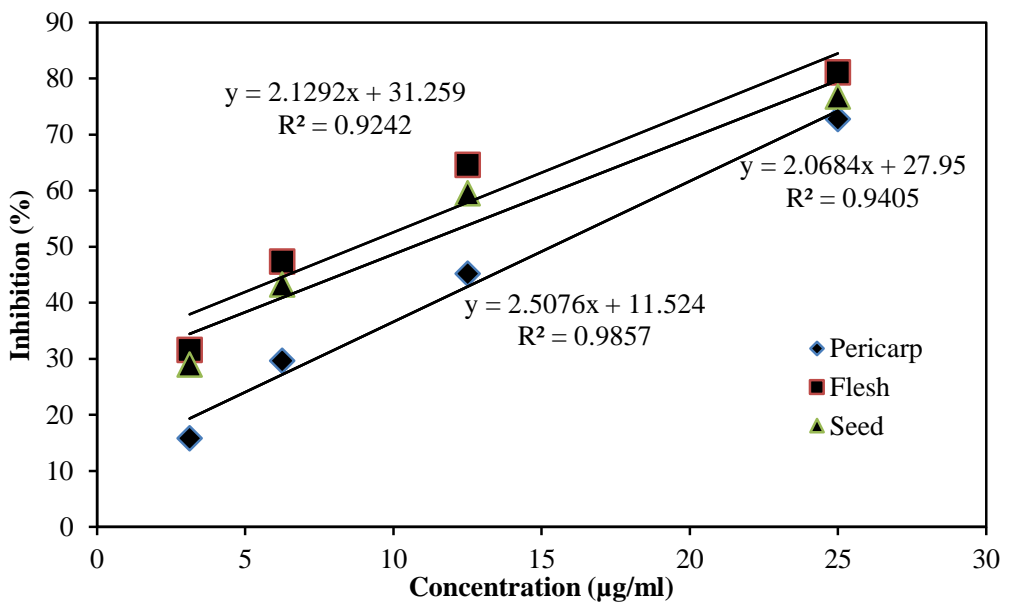

Figure 3. Antioxidant Activity in the Pericarp, Flesh and Seeds of Calamus caesius Bl., and Ascorbic Acid

Tabel 2. $\mathrm{IC}_{50}$ values of fruit of three rattan species and ascorbic acid

\begin{tabular}{lcc}
\hline \multicolumn{1}{c}{ Samples } & $\mathrm{IC}_{50}(\mu \mathrm{g} / \mathrm{ml})$ & Antioxidant Category* $^{*}$ \\
\hline Calamus manan Miq & & \\
$\quad$ Pericarp & 41.17 & Strong \\
Flesh & 170.19 & Moderate \\
Seed & 25.03 & Strong \\
Calamus caesius Bl. & & \\
$\quad$ Pericarp & 15.34 & Strong \\
Flesh & 8.80 & Strong \\
Seed & 10.66 & Strong \\
Calamus ornatus Bl. & & \\
$\quad$ Pericarp & 9.69 & Strong \\
Flesh & 88.82 & Active \\
Seed & 33.04 & Strong \\
Ascorbic Acid & 5.42 & Strong \\
\hline
\end{tabular}

* $\mathrm{IC}_{50}$ Value $<50 \mu \mathrm{g} / \mathrm{ml}$ Strong, $50 \mu \mathrm{g} / \mathrm{ml}-100 \mu \mathrm{g} / \mathrm{ml}$ Active, $100 \mu \mathrm{g} / \mathrm{ml}-250 \mu \mathrm{g} / \mathrm{ml}$ moderate, and $>500 \mu \mathrm{g} / \mathrm{ml}$ non active [14] 
Furthermore, in order to identify the effectiveness of sample in inhibiting free radical, the value of $\mathrm{IC}_{50}$ was calculated which was obtained from linear regression equation (Figure 1, 2, and 3) which expressed the correlation between sample extract concentration as an $\mathrm{x}$-axis and free radical inhibition as a y-axis. The results of calculation about the value of $\mathrm{IC}_{50}$ displayed on Table 2 showed that the three species of the fruit and the three different parts of the fruit had different antioxidant activities. The smaller the value of $\mathrm{IC}_{50}$ the stronger the antioxidant activities will be [14]. In the fruit of C. manan Miq., the power of antioxidant activities was successively ordered as follows: seeds > pericarp > flesh; in C caesius $\mathrm{Bl}$. flesh > seeds > pericarp, while in C.ornatus Bl. pericarp > seeds $>$ flesh. If compared with ascorbic acid as a positive control toward the three type of fruit, it was found that ascorbic acid $>C$. caesius $\mathrm{Bl} .>C$. ornatus Bl .> C.manan Miq. The antioxidant activities which were presented in order from the highest to the lowest activities can be illustrated as follows: the flesh of $C$. caesius Bl. $(8.80 \mu \mathrm{g} / \mathrm{ml})>$ the pericarp of Calamus caesius B1. $(9.69 \mu \mathrm{g} / \mathrm{ml})>$ the seeds of C.caesius $\mathrm{Bl}(10.66 \mu \mathrm{g} / \mathrm{ml})>$ the pericarp of C. caesius $\mathrm{Bl}(15.34 \mu \mathrm{g} / \mathrm{ml})>$ the seeds of $C$. manan Miq $(25.03 \mu \mathrm{g} / \mathrm{ml})>$ the seeds of Calamus ornatus B1. (33.04 $\mu \mathrm{g} / \mathrm{ml})>$ the pericarp of Calamus manan Miq $(41.17 \mu \mathrm{g} / \mathrm{ml})>$ the flesh of Calamus ornatus Bl. $(88.82 \mu \mathrm{g} / \mathrm{ml})>$ the flesh of Calamus manan Miq. (170.19 $\mu \mathrm{g} / \mathrm{ml})$ respectively. Ascorbic acid as a positive control has the highest antioxidant properties with $\mathrm{IC}_{50}$ values $5.42 \mu \mathrm{g} / \mathrm{ml}$. Based on the results of the phytochemical assay, antioxidant activities mostly influenced by the existence of flavonoids, tannins and triterpenoids compounds, which were detected almost in all species of rattan fruit in this study. Flavonoids are compounds which serve as antioxidant agents because their structure contains hydroxyl group which is able to give its hydrogen atom to free radical compounds so that it can inhibit a lot of oxidation reactions [15]. Jing [16] stated that the total flavonoids and phenol in Rhododendron anthopogonoides correlated significantly with antioxidant activities. A study on rattan fruit of $C$. tenuis Roxb was conducted by [5] showed that the total flavonoids correlated with the increasing antioxidant activities. Moreover, tannins as antioxidants have been discussed in the previous research findings. Rebaya [17] reported that there was a significant correlation between tannins, flavonoids and polyphenolic compounds and antioxidant activities in Halimium halimifolium. Bizuayehu [18] in their study also found that there was a positive correlation between tannins and antioxidant activities.

Triterpenoid is an antioxidant compound which serves as an antioxidant agent. Lin [19] stated that the increasing triterpenoid concentration will also increase the antioxidant activities in Garcinia lucidum. This indicates that triterpenoids play a role in increasing antioxidant activities. According to [20] triterpenoid content also strongly contributes to the antioxidant activities of mistletoe tea (Scurrula atropurpurea Bl. Dans).

\section{CONCLUSIONS AND SUGGESTION}

The fruit of $C$. caesius $\mathrm{Bl}$ has strong antioxidant activities in all parts of the tested fruit, while the fruits of $C$. manan Miq dan $C$. ornatus Bl. have strong antioxidant activities in its pericarp and seeds. Generally, the three species of rattan fruit have potentials as natural antioxidant agents based on the DPPH method, but the active compounds which play roles as 
antioxidant agents have not identified yet so that it is necessary to conduct further studies concerning this issue.

\section{ACKNOWLEDGMENT}

This research was funded by the Directorate General of Research and Development, The Ministry of Research, Technology and The Higher Education, Republic of Indonesia through the scheme of Doctoral Dissertation Grant 2017. The author extends his gratitude to the State Polytechnic of Agriculture, Samarinda for its facilities used to support this research.

\section{REFERENCES}

[1] Ripa, F., Dash, P., Podder, A., 2016. Anti-diarrheal and hypoglycemic activities of methanol extract of Calamus rotang L. seed in rat. Research Journal of Pharmacognosy (RJP). 3. 33-40.

[2] Rahman, M., Rahman, J., 2014. Medicinal value and nutrient status of indigenous fruits in Bangladesh. Nova Journal of Medical and Biological Sciences. 2. 1-19.

[3] Uddin, N., Islam, R., Hasan, N., Hossain, M. S., Roy, A., Hossain, M. M., Rana, M. S., 2011. DPPH scavenging assay of eighty four Bangladeshi medicinal plants. IOSR-JPBS. 6. 66-73.

[4] Ghosal, M., Mandal, P., 2013. In vitro antidiabetic and antioxidant activity of Calamus erectus Roxb. Fruit: A wild plant of Darjeeling Himalaya. Int J Pharm Bio Sci. 4. 671-684.

[5] Ahmed, Z. U., Bithi, S. S., Khan, M. M. R., Hossain, M. M., Sharmin, S., Rony, S. R., 2014. Phytochemical screening, antioxidant and cytotoxic activity of fruit extracts of Calamus tenuis Roxb. Journal of Coastal Life Medicine. 2. 645-650.
[6] Kokate, C., 2001. Pharmacohnosy. 16th Edn., Nirali Prakasham, Mumbai, India. Screening of various plant extracts used in ayurvedic medicine for inhibitory effects on human immunodeficience virus type I (HIV-I) protease. Phytother Res. 12. 488-493.

[7] Harborne, J., 1996. Metode Fitokimia, Terbitan ke-II, ab Kosasih Padmawinata. Penerbit ITB, Bandung.

[8] Arung, E. T., Kusuma, I. W., Christy, E. O., Shimizu, K., Kondo, R., 2009. Evaluation of medicinal plants from Central Kalimantan for antimelanogenesis. Journal of natural medicines. 63. 473-480.

[9] Khoo, H. E., Azlan, A., Kong, K. W., Ismail, A., 2016. Phytochemicals and medicinal properties of indigenous tropical fruits with potential for commercial development. Evidence-Based Complementary and Alternative Medicine. 2016.

[10] Salusu, H. D., Ariani, F., Obeth, E., Rayment, M., Budiarso, E., Kusuma, I. W., Arung, E. T., 2017. Phytochemical screening and antioxidant activity of selekop (Lepisanthes amoena) fruit. AGRIVITA, Journal of Agricultural Science. 39. 214-218.

[11] Matsuura, H. N., Fett-Neto, A. G. Plant alkaloids: main features, toxicity, and mechanisms of action. Plant Toxins: Springer; 2017. pp. 243-261.

[12] Konarska, A., Domaciuk, M., 2018. Differences in the fruit structure and the location and content of bioactive substances in Viburnum opulus and Viburnum lantana fruits. Protoplasma. 255. 25-41. 
[13] Kregiel, D., Berlowska, J., Witonska, I., Antolak, H., Proestos, C., Babic, M., Babic, L., Zhang, B. Saponin-based, biological-active surfactants from plants. Application and Characterization of Surfactants: InTech; 2017.

[14] Jun, M., 2003. J., Fong, X., Wan, CS, Yang, CT, Ho. Camparison of Antioxidant Activities of Isoflavones Form Kudzu Root (Puerarua labata O). Journal Food Science Institute of Technologist. 68. 2117-2122.

[15] Kumar, S., Pandey, A. K., 2013. Review Article Chemistry and Biological Activities of Flavonoids: An Overview, Hindawi Pub. Corp The Sci World Jour. 1-16.

[16] Jing, L., Ma, H., Fan, P., Gao, R., Jia, Z., 2015. Antioxidant potential, total phenolic and total flavonoid contents of Rhododendron anthopogonoides and its protective effect on hypoxia-induced injury in PC12 cells. BMC complementary and alternative medicine. 15. 287.

[17] Rebaya, A., Belghith, S. I., Baghdikian, B., Leddet, V. M., Mabrouki, F., Olivier, E., Cherif, J., Ayadi, M. T., 2014. Total phenolic, total flavonoid, tannin content, and antioxidant capacity of Halimium halimifolium (Cistaceae). Journal of Applied Pharmaceutical Science. 5. 52-57.
[18] Bizuayehu, D., Atlabachew, M., Ali, M. T., 2016. Determination of some selected secondary metabolites and their invitro antioxidant activity in commercially available Ethiopian tea (Camellia sinensis). SpringerPlus. 5. 412.

[19] Lin, M., Yu, Z., Wang, B., Wang, C., Weng, Y., Koo, M., 2015. Bioactive constituent characterization and antioxidant activity of Ganoderma lucidum extract fractionated by supercritical carbon dioxide. Sains Malays. 44. 1685-1691.

[20] Mustarichie, R., Runadi, D., Ramdhani, D., 2017. The Antioxidant Activity and Phytochemical Screening of Ethanol Extract, Fractions of Water, Ethyl acetate, and n-Hexane from $M$ istletoe Tea (Scurrula atropurpurea BL. Dans). Asian $J$ Pharm Clin Res. 10. 343-347. 